\title{
Efficacy of Anaerobic Soil Disinfestation for Control of Prunus Replant Disease
}

\author{
G. Browne, ${ }^{\dagger}$ N. Ott, A. Poret-Peterson, and H. Gouran, United States Department of Agriculture-Agricultural Research Service Crops Pa- \\ thology and Genetics Research Unit, Department of Plant Pathology, University of California, Davis; and B. Lampinen, Department of Plant \\ Sciences, University of California, Davis
}

\begin{abstract}
Prunus replant disease (PRD) is an important soilborne complex that suppresses growth and productivity of replanted stone fruit and nut orchards. It is effectively managed with preplant soil fumigation but, due to regulatory challenges, nonfumigant-based control strategies for PRD and other soilborne disease problems may become increasingly important, especially in California. We examined the potential of preplant anaerobic soil disinfestation (ASD) for control of PRD in four repeated orchard replant trials on sandy loam soil near Parlier, CA. After removal of the old orchard trees, alternative ASD treatments, all using rice bran as the main carbon source, were implemented, starting in late September. The alternative treatments incorporated rice bran at (i) $20 \mathrm{t} \mathrm{ha}^{-1}$, alone, in 3.0-m-wide row strips; (ii) $20 \mathrm{tha}^{-1}$, preceded by incorporation of a sudangrass cover crop and followed by drip application of molasses $\left(10 \mathrm{t} \mathrm{ha}^{-1}\right)$, in 3.0-m-wide row strips; (iii) $20 \mathrm{t} \mathrm{ha}^{-1}$, alone, in 1.8-m-wide strips; or (iv) $12 \mathrm{t} \mathrm{ha}^{-1}$, alone, in 1.8-m-wide strips. All ASD-treated areas were covered with clear tarp

and drip irrigated with $25 \mathrm{~cm}$ of water. Tarps remained for 6 weeks, during which the soil moisture level was kept at or above field capacity by drip irrigation. All trials included nontreated control and fumigated standard treatments. ASD raised temperature and reduced redox potential in soil at $15-$ and $46-\mathrm{cm}$ depths for 6 weeks. Fumigation and ASD treatments both nearly eradicated bioassay inoculum of Pythium ultimum in the soil before almond trees were replanted and significantly affected almond tree root communities of fungi and oomycetes after planting. Fumigation treatments and ASD treatments with rice bran at $20 \mathrm{t} \mathrm{ha}^{-1}$ in 3.0-m strips increased tree growth significantly and by similar magnitudes. Among repeated experiments, mean increases in trunk cross-sectional area growth due to fumigation ranged from 137 to $264 \%$, while the increases due to ASD at $20 \mathrm{t} \mathrm{ha}^{-1}$ in 3.0-m strips ranged from 148 to $214 \%$, compared with controls. ASD offers effective control of PRD and is worthy of further optimization and testing for management of PRD and additional orchard replant problems.
\end{abstract}

The steadily urbanizing Central Valley of California is plagued by air- and groundwater-quality problems and water shortages. The region hosts over 1.2 million acres of deciduous tree crops (NASS 2015), which often require preplant soil remediation to remain productive and efficient when they are replanted on the same land (Browne et al. 2013). Preplant soil fumigation with 1,3-dichloropropene (1,3-D) and chloropicrin currently provides one of the most effective and economical means by which to maximize efficiency of water, fertilizer, and land use in replanted orchards. However, soil fumigants are highly toxic and, as volatile organic compounds (VOCs), they contribute to the formation of ground-level ozone, which is a human health hazard (Ajwa et al. 2013; Gao et al. 2013). Due in large part to VOCs, regions of California, including parts of the Central Valley, have failed to meet standards of the U.S. Clean Air Act (CDFA 2009). Stringent regulation of fumigant use in California, designed to safely manage both acute and chronic risks to humans at local and regional levels, has intensified the need to develop alternatives to soil fumigation, especially for orchards in the Central Valley.

One such alternative, anaerobic soil disinfestation (ASD), has been researched and used commercially in annual cropping systems in Japan, The Netherlands, and the United States (Shennan et al. 2014; Strauss and Kluepfel 2015). Developed independently in The Netherlands (Blok et al. 2000) and Japan (Momma et al. 2005; Shinmura 2004) for use in field, vegetable, nursery, and greenhouse crops, ASD is now being adapted for strawberry production in California and vegetable and floriculture systems in the southeastern United States (Butler et al. 2012; Shennan et al. 2014). Compared with soil fumigation, ASD generally has provided similar levels of broad-spectrum control of soilborne fungal, oomycete, bacterial, and

${ }^{\dagger}$ Corresponding author: G. T. Browne;

E-mail: gregory.browne@ars.usda.gov

Current address of Dr. Gouran: Sutro Biopharma, Inc., South San Francisco, CA

Accepted for publication 7 August 2017.

This article is in the public domain and not copyrightable. It may be freely reprinted with customary crediting of the source. The American Phytopathological Society, 2017. nematode phytopathogens in many soils (e.g., sands, sandy loams, and loams) and substrates (e.g., coconut husk, cedar bark, and rock wool) (Shennan et al. 2014). ASD mechanisms appear to be multiple and complex, including generation of organic acids, metal ions, and volatiles under anaerobic conditions resulting in microbial population shifts and suppression of plant pathogens (Messiha et al. 2007; Momma et al. 2013; Shennan et al. 2014). ASD is implemented for several weeks and requires readily available carbon substrates, moist soil conditions, and coverage with plastic mulch, which raises soil temperature, retains moisture, and retards gas exchange (Shennan et al. 2014). High soil temperatures such as those found in summer and early fall in the Central Valley of California favor ASD, whereas low temperatures limit it. A variety of carbon substrates is being tested for ASD in efforts to maximize efficacy, reduce material and application costs, and reduce or eliminate the potential for leaching of nitrogen (Shennan et al. 2014; Strauss and Kluepfel 2015). Due to potential for pest-substrate-cropping system interactions, substrate efficacy and suitability tend to depend on the specific cropping system and its pests (Shennan et al. 2014; Strauss and Kluepfel 2015).

Though most ASD research has focused on annual cropping systems, it holds potential for perennial cropping systems as well. In recent walnut nursery trials, ASD induced pronounced microbial community shifts and effective suppression of Agrobacterium tumefaciens, the causal agent of crown gall disease (Strauss and Kluepfel 2015). Also, ASD has been shown to suppress apple replant disease pathogens and improve growth of apple seedlings in potted apple replant soils (Hewavitharana and Mazzola 2016). However, to our knowledge, no studies have examined ASD for management of an orchard replant problem under orchard conditions.

Common biological replant problems of stone fruit (e.g., almond, apricot, cherry, nectarine, peach, plum, and prune) can be grouped into two arbitrary categories: (i) Prunus replant disease (PRD), which is apparently mediated by an incompletely understood complex of Pythium spp., Cylindrocarpon spp., and likely additional soilborne microorganisms that suppress root system development, especially in the first few years after replanting (Bent et al. 2009; Browne et al. 2006, 2013; Schmidt and Browne 2013; Yang et al. 2012); and (ii) phytopathogenic nematodes (PPN) (e.g., ring, lesion, and root-knot nematode species, which can damage and debilitate plant root systems over the lifetime of an orchard) (McKenry and Kretsch 
1987). Based on recent surveys, $\mathrm{PRD}$ is expressed to some degree in over half of almond and stone fruit orchard soils in California (Browne et al. 2015a), whereas PPN may affect less than half of the acreage in the state (McKenry and Kretsch 1987). Severity of PRD is typically greatest in the first few years of a replanted orchard's development, whereas PPN can persist through an orchard's lifetime. Preplant fumigation treatments are effective in managing both PRD and PPN (Browne et al. 2006, 2013; McKenry 1999).

The main objective of this study was to determine whether ASD treatments that have been effective in annual cropping systems can be adapted for effective management of one key replant problem, PRD, under orchard conditions. A central concern for orchardists is whether or not the depth of ASD impact in soil can be sufficient for deeply rooted perennial crops, and this concern is best addressed by field testing. Here, we report on repeated trials of ASD treatments conducted on land subject to PRD but free from significant populations of PPN.

\section{Materials and Methods}

Soil and treatments. Two almond replant trials were established in 2013 to compare efficacy of preplant ASD and soil fumigation treatments for control of PRD. The trials (experiments 1 and 2) were conducted in adjacent areas located at the University of California (UC) Kearney Research and Education Center near Parlier, CA. The soil was Hanford fine silty loam (course-loamy, mixed, superactive, nonacid, thermic typic xerorthents). For at least 12 years before the trials, the land was used to grow nectarine trees (Prunus persica 'Fantasia' on 'Nemaguard' rootstock). Repeated soil sampling indicated that the soil did not have significant populations of PPN.

In preparation for experiment 1 , nectarine trees were removed from all plots in May (Table 1). The land was "ripped" to a depth of 0.6-m, disked, and leveled before initiation of differential preplant treatments. The treatments, which began in September, included (i) a nontreated control, (ii) ASD, and (iii) conventional shank fumigation (Table 1). Each treatment was applied to three replicate plots $(6.1$ by $27.4 \mathrm{~m}$ ) in a randomized complete block design. The control plots were kept free of weeds but were not otherwise treated. The preplant soil fumigation treatment, 1,3-D-chloropicrin $(61: 35$ [wt/wt] Telone C35; Dow Agrosciences) at $600 \mathrm{~kg} \mathrm{ha}^{-1}$ (rate on treated area), was applied 30 October to 3.6-m-wide strips that were centered in the 6.1-m plot width and ran full plot length; a "deep-shank fumigation rig" (TriCal, Inc.) with shanks spaced $51 \mathrm{~cm}$ apart was used to inject fumigant at a depth of 46 to $51 \mathrm{~cm}$ into soil. In keeping with commercial practice for orchard fumigation in California, a disk and ring roller were used to seal the fumigated soil without a tarp. ASD was implemented with rice bran (Farm Fuels Inc.) applied at $20 \mathrm{tha}^{-1}$ (treated area) in 3.0-m-wide strips centered in plot width and running the full plot length. The rice bran was incorporated with a rototiller to a depth of approximately $15 \mathrm{~cm}$ in the soil on 17 September. Drip irrigation lines (16-mm ID, 8-mil wall, 30-cm spacing, 1.64 liters $\mathrm{h}^{-1}$ $\mathrm{m}^{-1}$ at 0.55 bar; T-Tape; John Deere Water), spaced $30 \mathrm{~cm}$ apart, were pulled over the length of the bran-treated areas, connected to a water supply manifold, and covered with totally impermeable film (TIF) (1.0-mil clear Vapor Safe TIF; Raven Industries). The tarp edges were buried with soil. Starting within a day of rice bran incorporation, the ASD plots were irrigated with $25 \mathrm{~cm}$ of water. Subsequently, the plots were irrigated 0.5 to $1 \mathrm{~h}$ per day $(0.2$ to $0.5 \mathrm{~cm}$ of water). The tarps were removed from ASD plots on 6 November.

Preplant treatments for experiment 2 also began in May 2013 (Table 1). An unbalanced split plot design was used in which main plots ( 6.1 by $82.3 \mathrm{~m})$, arranged in five complete blocks, were assigned to treatments of tree removal in either May or September. Main plots from which trees were removed in May were seeded to Trudan 8 hybrid sudangrass (Wilbur-Ellis) 2 weeks later. The grass rotation was irrigated weekly as needed until early September, when it was

Table 1. Experiments and preplant treatment outline ${ }^{\mathrm{a}}$

\begin{tabular}{|c|c|c|c|}
\hline \multirow[b]{2}{*}{ Year, experiment, treatment description } & \multicolumn{3}{|r|}{ Treatment details } \\
\hline & Removal $^{\mathbf{b}}$ & Rotation $^{c}$ & Soil treatment after clearing all plots; treated area \\
\hline \multicolumn{4}{|l|}{2013} \\
\hline \multicolumn{4}{|l|}{1} \\
\hline Control, no sudangrass & May & None & None \\
\hline ASD w/rice bran, no sudangrass & May & None & ASD w/rice bran $20 \mathrm{t} \mathrm{ha}^{-1} ; 3.0$-m-wide strips \\
\hline Fumigation in Oct, no sudangrass & May & None & Fumigation in Oct w/1,3-D:Pic, $600 \mathrm{~kg} \mathrm{ha}^{-1} ; 3.4$-m-wide strips \\
\hline \multicolumn{4}{|r|}{$\mathrm{Cos}$} \\
\hline Control, no sudangrass & Sep & None & None \\
\hline Control, w/sudangrass & May & Jun-Aug & None \\
\hline $\begin{array}{l}\text { ASD w/rice bran + molasses, } \\
\text { w/sudangrass }\end{array}$ & May & Jun-Aug & ASD w/rice bran $20 \mathrm{t} \mathrm{ha}^{-1} \&$ molasses $10 \mathrm{tha}^{-1} ; 3.0$-m-wide strips \\
\hline Fumigation in Oct, no sudangrass & Sep & None & Fumigation in Oct, 1,3-D:Pic, $600 \mathrm{~kg} \mathrm{ha}^{-1}$; 3.4-m-wide strips \\
\hline Fumigation in Oct, w/sudangrass & May & Jun-Aug & Fumigation in Oct w/1,3-D:Pic, $600 \mathrm{~kg} \mathrm{ha}^{-1}$ of 3.4-m-wide strips \\
\hline Fumigation in Dec, no sudangrass & Sep & None & Fumigation in Dec w/1,3-D:Pic, $600 \mathrm{~kg} \mathrm{ha}^{-1}$; 3.4-m-wide strips \\
\hline \multicolumn{4}{|l|}{2014} \\
\hline \multicolumn{4}{|l|}{3} \\
\hline Control, no sudangrass & May & None & None \\
\hline ASD w/rice bran, no sudangrass & May & None & ASD w/rice bran $20 \mathrm{t} \mathrm{ha}^{-1} ; 3.0$-m-wide strips \\
\hline Fumigation in Oct, no sudangrass & May & None & Fumigation in Oct w/1,3-D:Pic, $600 \mathrm{~kg} \mathrm{ha}^{-1} ; 3.4$-m-wide strips \\
\hline \multicolumn{4}{|r|}{ 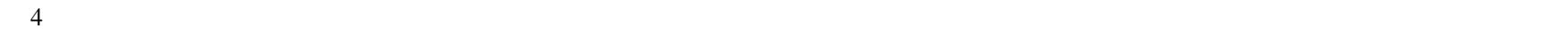 } \\
\hline Control, no sudangrass & Sep & None & None \\
\hline Control, w/sudangrass & May & Jun-Aug & None \\
\hline $\begin{array}{l}\text { ASD w/rice bran + molasses, } \\
\text { w/sudangrass }\end{array}$ & May & Jun-Aug & ASD w/rice bran, $20 \mathrm{t} \mathrm{ha}^{-1} \&$ molasses $10 \mathrm{t} \mathrm{ha}^{-1} ; 3.0$-m-wide strips \\
\hline $\begin{array}{l}\text { ASD w/rice bran (reduced trt area), no } \\
\text { sudangrass }\end{array}$ & Sep & None & $\mathrm{ASD}$, rice bran, $20 \mathrm{t} \mathrm{ha}^{-1} ; 1.8$-m-wide strips \\
\hline $\begin{array}{l}\text { ASD w/rice bran (reduced trt area \& } \\
\text { rate), no sudangrass }\end{array}$ & Sep & None & $\mathrm{ASD}$, rice bran, $12 \mathrm{t} \mathrm{ha}^{-1} ; 1.8$-m-wide strips \\
\hline Fumigation in Oct, no sudangrass & Sep & None & Fumigation, Oct, 1,3-D:Pic, $600 \mathrm{~kg} \mathrm{ha}^{-1} ; 3.4$-m-wide strips \\
\hline Fumigation in Oct, w/sudangrass & May & Jun-Aug & Fumigation, Oct, 1,3-D:Pic, $600 \mathrm{~kg} \mathrm{ha}^{-1}$; 3.4-m-wide strips \\
\hline
\end{tabular}

a Year of preplant treatment application. Abbreviations: ASD = anaerobic soil disinfestation, 1,3-D:Pic = Telone C35 formulation of 1,3-dichloropropenechlorpicrin $(63: 35, \mathrm{wt} / \mathrm{wt})$, trt $=$ treatment, Oct $=$ October, Sep $=$ September, Dec $=$ December, Jun $=$ June, and Aug $=$ August.

b Time of old orchard removal.

c Time of sudangrass rotation. 
mowed and then incorporated into the soil with a disk. Main plots that retained nectarine trees were irrigated weekly as needed until the trees were cleared from the plots in September. After the sudangrass incorporation and tree clearing, all of the main plots were ripped to a depth of $0.6 \mathrm{~m}$, disked, and leveled along with plots in experiment 1. Main plots that had been used for the sudangrass rotation were split into three plots ( 6.1 by $27.4 \mathrm{~m}$ each) that were randomly assigned to subplot treatments of (i) a control, (ii) ASD, or (iii) October preplant fumigation. Main plots that had been used to grow nectarine trees through the summer without a sudangrass rotation were split into three subplots ( 6.1 by $27.4 \mathrm{~m}$ each) that were randomly assigned to treatments of (i) control, (ii) October preplant fumigation, or (iii) December preplant fumigation. The control treatment, common to both main-plot treatments, was kept free of weeds but was not otherwise treated. The ASD treatment, given only within main plots that had received sudangrass rotation, was initiated 17 September as described for ASD in experiment 1, except that it was augmented with an application of sugar cane molasses (Farm Fuels Inc.) at $10 \mathrm{t} \mathrm{ha}^{-1}$ (treated area) through the drip irrigation lines on 11 October. The amount of molasses required was mixed with water at a ratio of 1:3 (molasseswater [vol/vol]) and then applied to the ASD plots through the drip irrigation lines within $1 \mathrm{~h}$ and followed with $4 \mathrm{~h}$ of irrigation. After molasses application, the experiment 2 ASD plots were managed like those of experiment 1. The October preplant fumigation treatment, common to both main plot treatments, was fumigated on 30 October, as described for the fumigation treatment of experiment 1 . The December fumigation treatment, given only in main plots that received no sudangrass rotation, was applied 10 December but otherwise was the same as the October fumigation treatment.

At the completion preplant treatments of experiment 1 and experiment 2, all plots in both experiments were cultivated and smoothed with a rototiller. Care was used to avoid dragging soil from one plot to another.

Temperature and redox potential in soil. The effect of ASD and control treatments on redox potential $\left(E_{h}\right)$ was monitored using Sensorex ORP sensors (model S500CD-ORP; Sensorex) connected to CR1000 dataloggers (Campbell Scientific); the ORP sensor output (based on $\mathrm{Ag} / \mathrm{AgCl}$ reference) was converted to standard hydrogen reference electrode output (the values reported) by adding 200 millivolts $(\mathrm{mV})$. Soil temperature was monitored in ASD and control plots using temperature sensors connected to a model 900M monitor (Irrometer). Depending on the experiment and treatment, soil $E_{h}$ and temperature were recorded at hourly intervals in one to three plots and at one or two soil depths ( 46 or 15 and $46 \mathrm{~cm}$ ) per treatment in each experiment. The $E_{h}$ and temperature data were averaged over 24-h periods, by treatment, for graphical presentation.

Survival of Pythium ultimum in soil bioassay. A bioassay with Pythium ultimum was used to partially assess impacts of the preplant ASD and fumigation treatments. Mycelium of P. ultimum was inoculated into sterile V8 juice-vermiculite-oat medium (previously autoclaved for $1 \mathrm{~h}$ on two successive days) in 250 -ml containers. The inoculated substrate was incubated for 2 weeks at 22 to $24^{\circ} \mathrm{C}$, then washed with water to remove unassimilated nutrients. The colonized substrate was mixed thoroughly with Hanford sandy loam (1:3, substrate-soil [vol/vol]) and packaged into close-fitting nylon bags $(10 \mathrm{ml} / \mathrm{bag}$ ) which, in turn, were attached to nylon cords; each cord received two bioassay bags, spaced $31 \mathrm{~cm}$ apart. Two cords, with bags attached, were used in each control, ASD, and fumigated treatment plot. Each cord was inserted into a separate, freshly dug 7-cm-diameter hole in the soil so that one of the attached bags was positioned at $46 \mathrm{~cm}$ below the surface and the other was at $15 \mathrm{~cm}$ below the surface. The bags were placed in soil just before their respective ASD and fumigation treatments were applied, and control plot placements of bioassay bags were made separately for ASD and fumigation treatments.

The bioassay bags were retrieved from soil 7 to 8 weeks after placement and used for dilution plating. Aliquots of soil from the bioassay bags were dried overnight in a laminar flow hood; then, separately, $1 \mathrm{~g}$ of dried soil from each bag was suspended in $10 \mathrm{ml}$ of sterile distilled water, vortexed for $30 \mathrm{~s}$, and used for two serial 1-to-10 dilutions. A 0.1$\mathrm{ml}$ aliquot of the final dilution was spread on 100-mm-diameter plates of a modified corn meal agar medium amended with pimaricin, ampicillin, rifampicin, and pentachloronitrobenzene (PARP) (Browne et al. 2015b) using an Eddy Jet spiral plater (IUL, S.A.). Over the next 24 to 48 h, the number of colonies on each plate was determined and expressed as CFU per gram of dry soil. Due to a lack of inoculum survival in several treatments and relatively high variance in other treatments, the CFU data were presented as treatment means with standard errors.

Growth of almond trees. In late January 2014, almond trees were planted in experiments 1 and 2. Each plot (experiment 1) or subplot (experiment 2) received a single row of eight trees of 'P16.013' almond on Nemaguard rootstock (Burchell Nursery, Clovis, CA). There were $6.1 \mathrm{~m}$ between rows in adjacent plots, and trees were spaced $3.0 \mathrm{~m}$ apart in rows. Using the same in-row spacing, single trees of experimental 'P13.019' almond on Nemaguard rootstock (Burchell Nursery, Inc., Fresno, CA) were planted to serve as "guard" trees on row-end plot boundaries. All of the trees had been grown in fumigated soil of the commercial nursery and provided as bare-root trees. Just after planting, the trees were watered with approximately 12 liters of water in a basin to settle the soil and ensure good soil-root contact. The trees were subsequently irrigated with a microsprinkler irrigation system; a single Fanjet (pattern J2; Bowsmith) was used per tree. The trees were irrigated according to crop evapotranspiration estimates provided by the California Irrigation Management System (http://www.cimis.water.ca. gov/). The required amount of irrigation water was applied at weekly intervals. Trees were fertilized with urea ammonium nitrate at recommended doses and frequency (http://apps.cdfa.ca.gov/frep/docs/AlmondBrochure. pdf). Foliage of the trees was sprayed with neutral zinc solution once during the season to prevent zinc deficiency.

Tree trunk circumference at $51 \mathrm{~cm}$ above the soil line was measured at planting and at yearly increments thereafter, during tree dormancy. The circumference data were used to calculate, annually, the increases in trunk cross-sectional area that had occurred since planting. In July of the second summer of tree growth, the midday photosynthetically active radiation (PAR) absorbed by the tree canopies, expressed as a percentage of total midday PAR, was determined using a mobile platform described previously (Lampinen et al. 2012).

Analysis of variance (ANOVA) was conducted for plant growth and PAR data using PROC MIXED of SAS/STAT software (version 9; SAS Institute). Before ANOVA, tree trunk cross-sectional area increases were averaged within experimental unit plots. In the MIXED model statements, trunk cross-sectional area growth and PAR data from experimental units were specified as a function of preplant soil treatment, and block was specified as a random effect. For significant treatment effects, means were separated according to $95 \%$ confidence intervals. In experiment 2 , due to the unbalanced split-plot treatment structure, it was necessary to conduct ANOVA separately for treatments that involved sudangrass rotation and those that did not. However, in addition, a factorial ANOVA for experiment 2 was completed after excluding treatments that did not occur in both sudangrass and no-sudangrass main plots. The factorial ANOVA specified response variables as a function of the balanced factorial treatment combinations, with block and block-sudangrass rotation treatment specified as random effects.

Fungal and oomycete community shifts on roots. Samples were collected in May 2014 from trees in experiment 1 to examine effects of the preplant soil treatments on incidence of culturable fungi and oomycetes in the roots. Fine roots were collected from soil that was 0.3 to $1 \mathrm{~m}$ in horizontal distance from the tree trunk and at a depth of 15 to $61 \mathrm{~cm}$. The roots were kept cool $\left(5\right.$ to $\left.10^{\circ} \mathrm{C}\right)$ and were used for isolations within 2 days on (i) one-fifth-strength potato dextrose agar amended with ampicillin at $50 \mathrm{mg} \mathrm{liter}^{-1}$ and (ii) modified PARP medium (Browne et al. 2015b). Before culturing, root pieces $1 \mathrm{~mm}$ or less in diameter were selected randomly from each sample and cut to lengths of $1 \mathrm{~cm}$. The root pieces were rinsed in sterile water, and half of them also were submerged in $0.6 \% \mathrm{NaOCl}$ for $1 \mathrm{~min}$, then rinsed three more times in sterile deionized water before culturing on the media. All isolates with hyphae were subcultured individually onto one-fifthstrength potato dextrose agar amended with ampicillin and, where possible, identified to genus level based on morphology.

In May and August 2014, root samples also were collected for culture-independent sampling of fungal and oomycete root communities associated with the preplant treatments of experiment 1 . The 
samples were collected exactly as described for the roots used for culturing, except that they were frozen on dry ice within a few minutes after collection and then transported within $24 \mathrm{~h}$ to long-term storage at $-80^{\circ} \mathrm{C}$ until use for DNA extraction and microbial analyses. For extraction, the root samples were ground into powder while still frozen using an MM 200 Mixer Mill homogenizer (Retsch; www.retsch. com). Total DNA was extracted using the MoBio PowerPlant Pro kit and further purified with MoBio PowerClean Pro kit (Mo Bio Laboratories, Inc.). DNA quality and quantity was measured using a NanoDrop 1000 spectrophotometer (Thermo Scientific) and a Qubit 2.0 fluorometer (Thermo Scientific), respectively. Ratios of $>1.7$ were acheived for absorbance $260 / 280 \mathrm{~nm}$ in the purified DNA before polymerase chain reaction (PCR). BITS F and B58S3R primers (Bokulich and Mills 2013) were used to amplify the ITS 1 region of fungal communities. PCR was carried out in an Eppendorf Mastercycler (Eppendorf) using 25- $\mu$ l reaction mixtures containing $3 \mathrm{mM}$ $\mathrm{MgCl}_{2}, 0.04 \mathrm{mM}$ dNTPs, $0.2 \mu \mathrm{M}$ barcoded BITS forward primer, $0.2 \mu \mathrm{M}$ B58S3 reverse primer, $1 \times$ buffer, and 1U Taq (New England Biolabs catalog \#E5000S). The reaction parameters were: initial denaturing at $95^{\circ} \mathrm{C}$ for $2 \mathrm{~min} ; 34$ cycles of denaturing at $95^{\circ} \mathrm{C}$ for $30 \mathrm{~s}$, annealing at $55^{\circ} \mathrm{C}$ for $30 \mathrm{~s}$, and extension at $72^{\circ} \mathrm{C}$ for $1 \mathrm{~min}$; and a final extension at $72^{\circ} \mathrm{C}$ for $5 \mathrm{~min}$. PCR products were electrophoresed on a $1 \%$ agarose gel to verify amplification and, based on product band brightness in the gels, pooled to achieve similar concentrations of PCR product representation among samples. The pooled libraries were cleaned and concentrated using $0.8 \times$ Agencourt AMPure magnetic beads and a MagnaRack magnetic separation rack (Thermo Fisher Scientific), with elutionin to $30 \mu \mathrm{l}$ of TruSeq Resuspension Buffer (Illumina). The libraries were submitted to DNA Technologies at UC Davis for Illumina library preparation. A bioanalyzer trace (Bioanalyzer 2100; Agilent) showed a peak of fragment size from 250 to 500 bp. The libraries were sequenced by the Core Sequencing Facility at UC Davis DNA in a shared PE 250 Illumina MiSeq run.

Bioinformatics. PANDAseq was used to merge paired-end reads from the Miseq run with default parameters (Masella et al. 2012). The merged sequences were then demultiplexed and quality screened to remove sequences longer than $480 \mathrm{bp}$, containing ambiguous nucleotides, or with homopolymers longer than $8 \mathrm{bp}$ in mothur (Schloss et al. 2009). Operational taxonomic unit (OTU) clustering was performed in USEARCH (Edgar 2010), generally following recently described workflows (Bálint et al. 2014), and UFITS (https://github.com/ nextgenusfs/ufits). Briefly, the sequences were padded with terminal Ns using the fasta_trim_pad.py script from UFITS. These padded sequences were dereplicated, sorted by size with discarding of singletons, and clustered into OTUs (threshold of 0.97) with simultaneous de novo chimera checking. After removal of terminal Ns, representative OTU sequences were classified against UNITE + INSD (v6_sh_97) using the naïve Bayesian classifier, with a cutoff of 0.80 (Wang et al. 2007) implemented in mothur. To identify oomycete-affiliated OTUs, representative sequences not classifiable to a fungal phylum were BLASTed against the National Center for Biotechnology Information nr database (Altschul et al. 1990). Finally, representative OTUs classified as fungi or oomycetes were mapped to input sequences to generate an OTU table. After processing, we obtained 36 libraries (18 for each experiment), with sizes of 5,900 to 301,821 sequences, constituting 418 OTUs.

The sequence libraries and taxonomic classifications were imported into $\mathrm{R}$ via phyloseq (R Core Development Team 2016) (McMurdie and Holmes 2013) and used to determine whether control, ASD-treated, or fumigated soils had significantly different rhizosphere microbial communities. To address this, we made a Bray-Curtis dissimilarity matrix of subsampled libraries with an equal number of sequences for each sample in an experiment (numbers of sequences subsampled per library in experiment 1 and experiment 3 were 5,900 and 24,347, respectively). The distance matrices were visualized using nonmetric multidimensional scaling (NMDS) and subjected to permutational ANOVA (permANOVA, 999 permutations), with samples grouped by soil treatment and month as blocking variable to test for significant differences in community structure. The above analyses were performed using the vegdist and metaMDS functions, respectively, in the R package vegan (Oksanen et al. 2016).
Repeats of experiments. Experiments 1 and 2, which received treatments in 2013, were repeated in 2014 as experiments 3 and 4, respectively, with some modifications (Table 1). The treatments, methods, and scheduling used for experiments 3 and 4 generally were the same as those used for experiments 1 and 2, respectively, with the following exceptions. In experiment 3 , due to unavailability of sufficient numbers of P16.013 trees, it was necessary to substitute 'Lonestar' almond on Nemaguard rootstock. Also, in experiment 4, the December preplant fumigation treatment was exchanged for two additional ASD treatments, which applied rice bran at either $20 \mathrm{t} \mathrm{ha}^{-1}$ or $12 \mathrm{t} \mathrm{ha}^{-1}$ to 1.8- $\mathrm{m}$ wide strips that ran the length of half-size plots measuring 6.1 by $13.7 \mathrm{~m}$. In the two additional ASD treatments, TIF tarp was used to cover only the $1.8-\mathrm{m}$-wide treated strip, adjacent to which the tarp edges were buried. In experiment 4 , the redox and temperature sensors were used only at the 46-cm soil depth, with sensors placed in two to three plots per treatment monitored.

Repeats of $P$. ultimum bioassays (i.e., in experiments 3 and 4), and culture-independent fungal and oomycete community assessments (experiment 3) were conducted, generally as described for experiments 1 and 2 . An exception was that, in experiment 3, root sampling for the culture-independent assessments occurred in July and November instead of in May and August. The fungal and oomycete amplicon libraries from experiment 1 and experiment 3 were sequenced in one MiSeq run.

\section{Results}

Temperature and redox potential in soil. In experiments 1 and 2, which were initiated in September 2013, soil temperatures declined as days shortened and weather cooled but the ASD treatments in both experiments raised soil temperatures by approximately $5^{\circ} \mathrm{C}$ at 15- and 46-cm soil depths during the 6-week treatment period, compared with the controls (Fig. 1A and B). Also, in both trials, the ASD treatments quickly established and generally maintained anaerobic conditions (i.e., $E_{h}<200 \mathrm{mV}$ ) (Husson 2013), whereas the monitored soil in control treatments generally remained aerobic (i.e., $E_{h}>$ $200 \mathrm{mV}$ ) (Fig. 1C and D). In experiments 3 and 4, which were initiated in September 2014 and were generally repeats of experiments 1 and 2, respectively, the ASD treatments again elevated soil temperatures and generated anaerobic conditions (Fig. 1E to H). Depending on the experiment and treatment, monitored ASD treatments accumulated an estimated 229,688 to 549,849 millivolt hours (mVh) below $E_{h}$ of $200 \mathrm{mV}$ (Table 2). In experiments where redox potential was monitored at both 15 and $46 \mathrm{~cm}$, accumulations of $\mathrm{mVh}<200 \mathrm{mV}$ were 1.1 to 1.7 times greater at $46 \mathrm{~cm}$ than at $15 \mathrm{~cm}$ (Table 2, experiments 1 to 3 ). In experiment 4 , which included three ASD treatments, all three treatments accumulated more than $350,000 \mathrm{mVh}$ at $<200 \mathrm{mV}$.

Survival of $\boldsymbol{P}$. ultimum in soil bioassay. All of the fumigation and ASD treatments tested eradicated or nearly eradicated bioassay inoculum of $P$. ultimum (Table 3, experiments 1 through 4, all assay sets). Survival of the bioassay inoculum in controls was variable but relatively high (i.e., means of 1,185 to $6,383 \mathrm{CFU} \mathrm{g}^{-1}$ of soil) (Table 3 , experiments 1 through 4 , all assay sets).

Growth of almond trees. In experiment 1 , the preplant treatments (control, ASD, and strip fumigation, all without a preceding rotation of sudangrass) exhibited highly significant effects on trunk crosssectional area increases in growing years 1 and $2(P=0.0001$ and $P<0.0001$, respectively) and on the percentage of PAR absorbance in growing year $2(P<0.0001)$. Compared with the control, the ASD with rice bran and fumigation with Telone $\mathrm{C} 35$ increased trunk crosssectional area growth by 172 and $173 \%$, respectively, in growing year 1 and by 93 and 84\%, respectively, in growing year 2 (Fig. 2A). Similarly, the ASD and fumigation treatments increased percent PAR absorbed by 108 and 94\%, respectively, compared with the control, in growing year 2 (Fig. 3A).

In experiment 2, one-way analyses of variance (ANOVAs) that were conducted separately for subplot treatments nested in sudangrass rotation main plots and subplot treatments nested in nonsudangrass main plots indicated highly significant treatment effects on trunk cross-sectional growth $(P<0.0001$, both sets of main plots, both growing years) and PAR $(P<0.0001$, growing year 2$)$. In growing year 1 of experiment 2 , 
the control treatment with sudangrass rotation increased trunk crosssectional area growth by $39 \%$, compared with the control without sudangrass rotation, but a $195 \%$ growth increase resulted when the sudangrass rotation was followed by ASD with rice bran and molasses (Fig. 2B). Similar increases in trunk growth resulted in growing year 1 from either of the fumigation treatments (i.e., fumigation in October or December), with or without sudangrass rotation (160 to $185 \%$, compared with the control without sudangrass rotation)
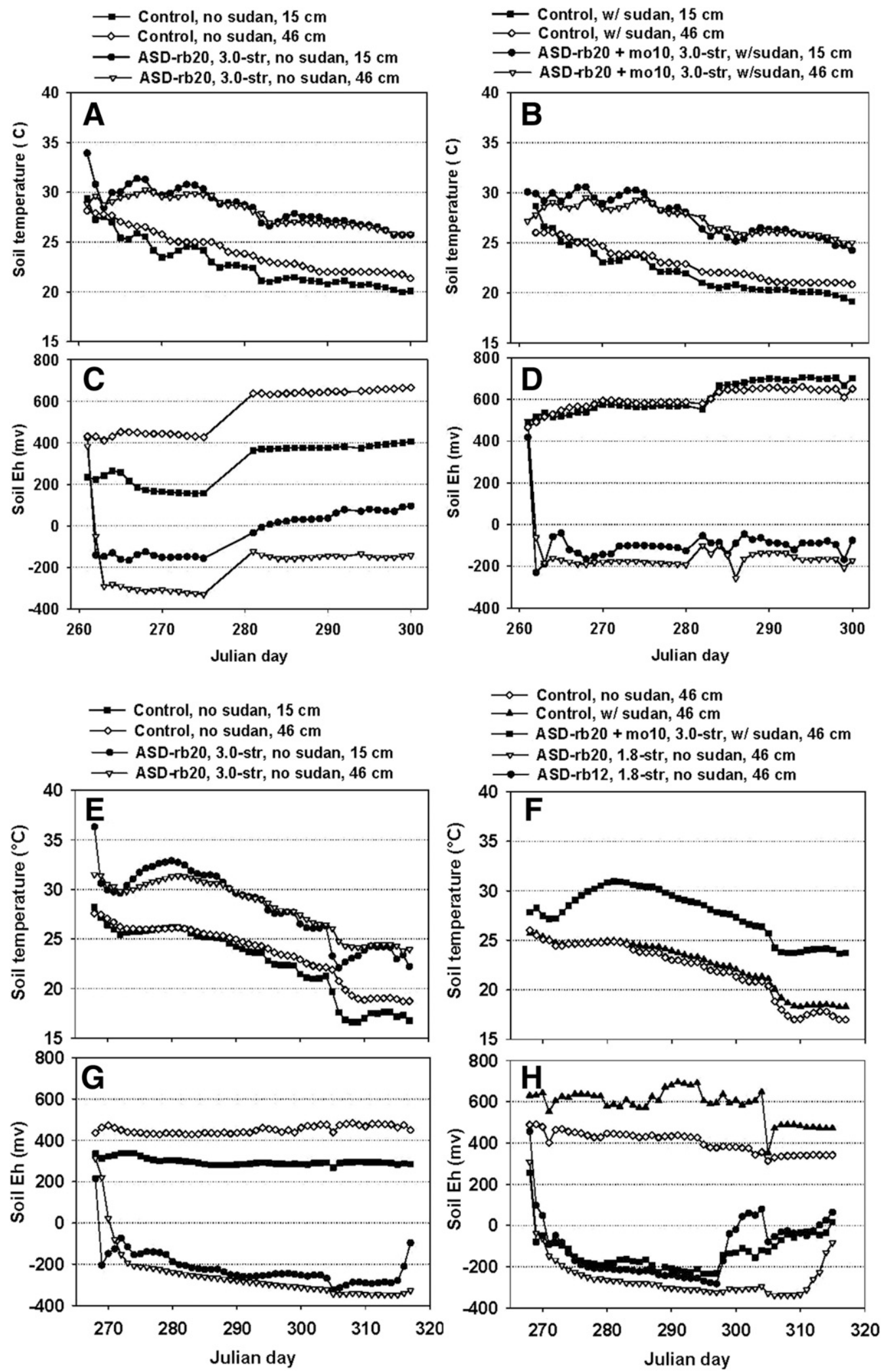

Fig. 1. Effects of anaerobic soil disinfestation (ASD) and control treatments on soil temperature and redox potential $\left(E_{h}\right)$ at indicated depths in soil. $\mathbf{A}$ and $\mathbf{B}$, Soil temperature in experiments 1 and 2, respectively; $\mathbf{C}$ and $\mathbf{D}$, redox potentials in experiments 1 and 2, respectively; $\mathbf{E}$ and $\mathbf{F}$, soil temperatures in experiments 3 and 4 , respectively; and $\mathbf{G}$ and $\mathbf{H}$, redox potentials in experiments 3 and 4 , respectively. In the legends, abbreviations of "rb20" and "rb12" indicate that rice bran was rototilled into soil at rates of 20 and $12 \mathrm{t} \mathrm{ha}^{-1}$ (treated area), respectively, whereas "mo-10" indicates addition of molasses at $10 \mathrm{t} \mathrm{ha}^{-1}$ via drip application. Also, "3.0-str" and "1.8-str" indicate 3.0- and 1.8-m-wide ASD-treated areas, respectively. 
(Fig. 2B). By the end of growing year 2 of experiment 2, the control treatment with preplant sudangrass rotation had increased trunk cross-sectional area growth by $23 \%$, compared with the control without sudangrass rotation. Following the sudangrass rotation with ASD using rice bran plus molasses maintained a trunk cross-sectional growth increase of $102 \%$, compared with the control without sudangrass. The fumigation treatments, with or without sudangrass rotation, sustained 79 to $88 \%$ increases in trunk cross-sectional growth, compared with the no-sudangrass control, in growing year 2 (Fig. 2B). Percent PAR absorbed in growing year 2 was approximately doubled by the ASD and fumigation treatments, compared with the control without sudangrass rotation (Fig. 3B). The 95\% confidence interval for mean percent PAR absorbed in the control with sudangrass rotation overlapped with that of the control without sudangrass rotation (Fig. 3B).

Two-way ANOVA on data only from the balanced, factorial treatments of experiment 2 (i.e., the subplot treatments of October fumigation and no fumigation, and the main plot treatments of sudangrass rotation and no rotation) indicated that trunk cross-sectional growth responded positively and significantly to October fumigation $(P<$ 0.0001 for both growing years $)$ and sudangrass rotation $(P=0.004$ and 0.008 for growing years 1 and 2, respectively). Trunk crosssectional growth exhibited no significant soil fumigation-sudangrass rotation interaction $(P=0.45$ and 0.13 for growing years 1 and 2 , respectively). Preplant fumigation in October increased trunk crosssectional area growth by $66 \%$, compared with no fumigation, across the main plot treatments with and without sudangrass rotation. Sudangrass rotation increased trunk cross-sectional area growth by $11 \%$, compared with no sudangrass rotation, across subplot treatments with and without October fumigation. The same balanced factorial ANOVA approach for PAR data from experiment 2 in growing year 2 revealed significant PAR increases due to soil fumigation $(P<0.0001)$ but not due to sudangrass rotation $(P=0.11)$, and there was no significant fumigation-sudangrass treatment interaction $(P=0.33)$.

In experiment 3 , which was a repeat of experiment 1 , the soil treatments again had highly significant effects on trunk cross-sectional area increases in both growing years $(P<0.0002$ for growing year 1 and $P=0.002$ for growing year 2). Compared with the control,

Table 2. Effects of preplant treatments on estimated millivolt hours ( $\mathrm{mVh}$ ) accumulated at anaerobic redox levels (less than $200 \mathrm{mV}$ ) ${ }^{\mathrm{a}}$

\begin{tabular}{|c|c|c|c|}
\hline $\operatorname{Exp}$ & Treatment description & $\begin{array}{l}\text { Soil depth } \\
(\mathrm{cm})\end{array}$ & $\underset{\text { mVh }^{\mathbf{b}}}{\text { Cumulative }}$ \\
\hline \multirow[t]{4}{*}{1} & Control, no sudangrass & 15 & 7,741 \\
\hline & $\ldots$ & 46 & 0 \\
\hline & ASD w/rice bran, no sudangrass & 15 & 229,668 \\
\hline & $\ldots$ & 46 & 384,794 \\
\hline \multirow[t]{4}{*}{2} & Control, w/sudangrass & 15 & 0 \\
\hline & $\ldots$ & 46 & 0 \\
\hline & $\begin{array}{l}\text { ASD w/rice bran + molasses, } \\
\text { w/sudangrass }\end{array}$ & 15 & 286,716 \\
\hline & .. & 46 & 341,812 \\
\hline \multirow[t]{4}{*}{3} & Control, no sudangrass & 15 & 0 \\
\hline & .. & 46 & 0 \\
\hline & ASD w/rice bran, no sudangrass & 15 & 501,900 \\
\hline & .. & 46 & 549,849 \\
\hline \multirow[t]{5}{*}{4} & Control, no sudangrass & 46 & 0 \\
\hline & Control, w/sudangrass & 46 & 0 \\
\hline & $\begin{array}{l}\text { ASD w/rice bran + molasses, } \\
\text { w/sudangrass }\end{array}$ & 46 & 388,597 \\
\hline & $\begin{array}{l}\text { ASD w/rice bran (reduced trt area), } \\
\text { no sudangrass }\end{array}$ & 46 & 539,641 \\
\hline & $\begin{array}{l}\text { ASD w/rice bran (reduced trt area } \& \\
\text { rate), no sudangrass }\end{array}$ & 46 & 368,317 \\
\hline
\end{tabular}

\footnotetext{
a Abbreviations: $\operatorname{Exp}=$ experiment, $\mathrm{ASD}=$ anaerobic soil disinfestation, and trt $=$ treatment

${ }^{\mathrm{b}}$ Estimated cumulative millivolt hours at $<200 \mathrm{mV}$.
}

the ASD and fumigation preplant treatments increased trunk crosssectional area growth by 148 and $137 \%$, respectively, in growing year 1 and by 78 and 71\%, respectively, in growing year 2 (Fig. 4A).

In experiment 4 , which was a modified repeat of experiment 2 , one-way ANOVA conducted separately for subplot treatments nested in with-sudangrass and no-sudangrass main plots again indicated highly significant effects of the subplot treatments on increases in trunk cross-sectional growth $(P<0.0001$ for both sets of subplot treatments in growing years 1 and 2). The original ASD treatment (i.e., with rice bran at $20 \mathrm{t} \mathrm{ha}^{-1}$ and molasses at $10 \mathrm{t} \mathrm{ha}^{-1}$ in $3.0-\mathrm{m}$ wide strips, following sudangrass rotation) and both fumigation treatments (October fumigation, with and without sudangrass rotation) again provided strong, equivalent increases in trunk cross-sectional growth (207 to 264\% in growing year 1 and 107 to $140 \%$ in growing year 2, compared with the control treatment without sudangrass rotation) (Fig. 4B). The reduced-input ASD treatments, which applied rice bran at either 20 or $12 \mathrm{t} \mathrm{ha}^{-1}$ to 1.8 -m-wide strips, without molasses and without a preceding sudangrass rotation, also increased trunk cross-sectional growth but not as much as the ASD treatment applied to 3.0-m strips with rice bran at $20 \mathrm{t} \mathrm{ha}^{-1}$ and molasses at $10 \mathrm{t} \mathrm{ha}^{-1}$ following sudangrass rotation. In growing year 1 , the 20 and $12 \mathrm{t} \mathrm{ha}^{-1}$ treatments in $1.8-\mathrm{m}$ strips increased trunk crosssectional growth by 169 and $78 \%$, respectively, compared with the control without sudangrass rotation. By growing year 2 , the 20 and $12 \mathrm{t} \mathrm{ha}^{-1}$ treatments in $1.8-\mathrm{m}$ strips had maintained trunk growth increases of 78 and $35 \%$, respectively, compared with the control (Fig. 4B).

Use of two-way ANOVA with only the balanced factorial treatment structure of experiment 4 (i.e., including only subplot treatments of October fumigation and no fumigation and main plot treatments of sudangrass rotation and no rotation) indicated that trunk cross-sectional growth was significantly increased by soil fumigation $(P<0.0001$ in growing years 1 and 2$)$ and by sudangrass rotation ( $P=0.006$ and 0.04 in growing years 1 and 2 , respectively). There was no highly significant fumigation-sudangrass interaction in growing year $1(P=0.11)$ but the interaction was significant in year $2(P=0.009)$. In growing year 1 , preplant fumigation in October increased trunk cross-sectional area growth by $189 \%$, compared with no fumigation, across treatments with and without sudangrass rotation, whereas sudangrass rotation increased trunk cross-sectional area growth by $22 \%$, compared with no sudangrass rotation, across fumigated an nonfumigated treatments. By growing year 2, fumigation without a preceding sudangrass rotation had increased trunk growth by $107 \%$, compared with the nonfumigated, nonsudangrass control, whereas fumigation following sudangrass rotation had increased trunk growth by $140 \%$, compared with the control. Sudangrass rotation alone improved trunk growth by only $8 \%$, compared with the control without sudangrass rotation.

Isolations of fungi and oomycetes from roots. Samples of the fine roots collected in May of growing year 1 in experiment 1 yielded multiple genera of fungi and oomycetes (Table 4). In the control soil treatment, Fusarium was the most prevalent genus, followed by Pythium and Mortierella (Table 4; 50, 41, and 35 isolates, respectively, from 192 cultured root pieces, counts from both isolation media and bleached and rinsed roots combined). In contrast, in the fumigation treatment, genus Trichoderma was isolated most frequently (89 isolates). Counts of Fusarium spp. were significantly reduced by either ASD or preplant fumigation ( $\chi^{2}$ test, $P=0.01$ ), whereas the counts of Pythium spp. were reduced significantly by fumigation $(P=0.01)$ and only marginally by $\operatorname{ASD}(P=0.10)$. The counts of Mortierella spp. were increased by fumigation $(P=0.01)$ and not affected significantly by $\operatorname{ASD}(P=0.33)$.

Ordination of sequenced fungal and oomycete community shifts on roots. After (i) quality screening of the merged internal transcribed spacer sequences amplified from the roots sampled from experiments 1 (2013) and 3 (2014) and (ii) removal of singletons from each sample, there were 312 and 286 OTU, $(1,637,618$ and 3,054,975 sequences) remaining from experiments 1 and 3 , respectively. When Bray-Curtis dissimilarity matrices constructed from the remaining OTUs were subjected to PERMANOVA with samples grouped 
by preplant treatment (i.e., control, ASD, and fumigation), there was a significant effect of soil treatment in $2013(P=0.001)$ but not in $2014(P=0.215)$. The significant effect of soil treatment was visible in an NMDS ordination of the 2013 Bray-Curtis dissimilarity matrix, in which root sample communities tended to cluster by soil treatment and sampling date (Fig. 5, stress $=0.178$ ) The clustering was less distinct in the NMDS ordination of the dissimilarity matrix from 2014 (Fig. 6, stress $=0.180$ ). In 2013, there was also a significant interaction $(P=0.001)$ between soil treatment and sampling month although, in 2014, the interaction was nonsignificant $(P=0.117)$. The effect of sampling month was marginally significant in $2013(P=0.054)$ and not significant in 2014 $(P=0.718)$.

\section{Discussion}

Our data indicate that ASD, implemented in 3.0-m-wide strips with rice bran alone at $20 \mathrm{t} \mathrm{ha}^{-1}$ can provide good control of PRD, equivalent to that provided by optimal preplant soil fumigation with 1,3-D plus chloropicrin. Our trials confirmed this efficacy through two growing seasons after planting, which covers the most critical period of PRD impacts (Browne et al. 2013). These conclusions are based on tree trunk cross-sectional area growth and PAR interception data, which tend to correlate positively with potential for nut yield in almond trees (Browne et al. 2013; Lampinen et al. 2012). To our knowledge, this is the first report of ASD efficacy for management of an orchard replant disease under field conditions, though ASD was documented to effectively suppress A. tumefaciens

Table 3. Effects of preplant treatments on survival of Pythium ultimum in bioassaya

\begin{tabular}{|c|c|c|c|c|c|}
\hline Exp & Assay set & Treatment description & Soil depth $(\mathbf{c m})$ & $\operatorname{Mn}\left(\mathrm{CFU} \mathrm{g}^{-1}\right)$ & SE \\
\hline \multirow[t]{8}{*}{1} & 1 & Control, no sudangrass & 15 & 5,717 & 994 \\
\hline & & $\ldots$ & 46 & 6,383 & 2,036 \\
\hline & & ASD w/rice bran, no sudangrass & 15 & 0 & 0 \\
\hline & & $\ldots$ & 46 & 0 & 0 \\
\hline & 2 & Control, no sudangrass & 15 & 3,667 & 1,135 \\
\hline & & $\ldots$ & 46 & 4,167 & 775 \\
\hline & & Fumigation in Oct., no sudangrass & 15 & 0 & 0 \\
\hline & & $\ldots$ & 46 & 0 & 0 \\
\hline \multirow[t]{16}{*}{2} & 1 & Control, with sudangrass & 15 & 6,140 & 450 \\
\hline & & $\ldots$ & 46 & 3,180 & 801 \\
\hline & & ASD w/rice bran + molasses, w/sudangrass & 15 & 0 & 0 \\
\hline & & $\ldots$ & 46 & 20 & 20 \\
\hline & 2 & Control, no sudangrass & 15 & 4,170 & 721 \\
\hline & & $\ldots$ & 46 & 4,460 & 238 \\
\hline & & Control, with sudangrass & 15 & 3,850 & 775 \\
\hline & & $\ldots$ & 46 & 4,230 & 615 \\
\hline & & Fumigation in Oct., no sudangrass & 15 & 0 & 0 \\
\hline & & $\ldots$ & 46 & 0 & 0 \\
\hline & & Fumigation in Oct., w/sudangrass & 15 & 0 & 0 \\
\hline & & $\ldots$ & 46 & 0 & 0 \\
\hline & 3 & Control, no sudangrass & 15 & 4,300 & 384 \\
\hline & & $\ldots$ & 46 & 4,392 & 558 \\
\hline & & Fumigation in Dec, no sudangrass & 15 & 0 & 0 \\
\hline & & $\ldots$ & 46 & 0 & 0 \\
\hline \multirow[t]{6}{*}{3} & 1 & Control, no sudangrass & 15 & 3,550 & 1,413 \\
\hline & & $\ldots$ & 46 & 1,533 & 597 \\
\hline & & Fumigation in Oct, no sudangrass & 15 & 0 & 0 \\
\hline & & $\ldots$ & 46 & 8 & 8 \\
\hline & & ASD w/rice bran, no sudangrass & 15 & 0 & 0 \\
\hline & & $\ldots$ & 46 & 0 & 0 \\
\hline \multirow[t]{18}{*}{4} & 1 & Control, no sudangrass & 15 & 1,185 & 350 \\
\hline & & $\ldots$ & 46 & 1,385 & 548 \\
\hline & & Control, w/sudangrass & 15 & 2,435 & 827 \\
\hline & & $\ldots$ & 46 & 1,630 & 556 \\
\hline & & ASD w/rice bran + molasses, w/sudangrass & 15 & 0 & 0 \\
\hline & & $\ldots$ & 46 & 0 & 0 \\
\hline & & $\begin{array}{l}\text { ASD w/rice bran (reduced trt area), no } \\
\text { sudangrass }\end{array}$ & 15 & 0 & 0 \\
\hline & & $\ldots$ & 46 & 0 & 0 \\
\hline & & $\begin{array}{l}\text { ASD w/rice bran (reduced trt area \& rate), no } \\
\text { sudangrass }\end{array}$ & 15 & 0 & 0 \\
\hline & & $\ldots$ & 46 & 5 & 5 \\
\hline & 2 & Control, no sudangrass & 15 & 3,085 & 261 \\
\hline & & $\ldots$ & 46 & 2,610 & 515 \\
\hline & & Control, w/sudangrass & 15 & 2,225 & 360 \\
\hline & & $\ldots$ & 46 & 2,430 & 296 \\
\hline & & Fumigation in Oct, no sudangrass & 15 & 0 & 0 \\
\hline & & $\ldots$ & 46 & 190 & 190 \\
\hline & & Fumigation in Oct, w/sudangrass & 15 & 0 & 0 \\
\hline & & $\ldots$ & 46 & 0 & 0 \\
\hline
\end{tabular}

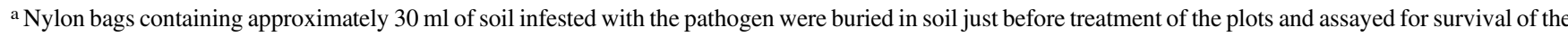
pathogen after treatment. Abbreviations: Exp = experiment, $\mathrm{SE}=$ mean standard error, $\mathrm{ASD}=$ anaerobic soil disinfestation, $\mathrm{Oct}=\mathrm{October}$, Dec $=\mathrm{December}$, and trt $=$ treatment. 
under field conditions in a simulated walnut nursery (Strauss et al. 2017).

The soil redox, temperature, and bioassay data collected in this study indicate that ASD impacts reached to a soil depth of at least $46 \mathrm{~cm}$, well beyond the depth of rice bran incorporation (approximately $15 \mathrm{~cm}$ ). This is an important consideration, given that the ultimate depth of rooting of perennial fruit and nut trees can extend beyond $3 \mathrm{~m}$ (Catlin 1996). Based on our sampling in this study, the new roots most affected by PRD in the first year of growth after tree planting tend to be concentrated between soil depths of 15 to $60 \mathrm{~cm}$, and impacts of ASD on temperature, redox potential, and $P$. ultimum survival were similarly evident at a $46-\mathrm{cm}$ depth, compared with a $15-\mathrm{cm}$ depth in soil. In our experience, good control of PRD in the first 2 years after planting shows a persistent positive effect on the trees. It is uncertain whether ASD will provide adequate control of PPN, which can survive at soil depths considerably greater than $1 \mathrm{~m}$.
Our data suggest that temperature and solar radiation levels occurring in the Central Valley are well suited to implementation of ASD. Although the ASD treatments were not initiated until late September (well beyond peak average summer temperatures and day length), substantial totals of millivolt hours below $E_{h}$ of $200 \mathrm{mV}$ were accumulated (229,668 to $549,849 \mathrm{mVh}$, depending on the experiment). These exceeded accumulations typically measured in ASD trials conducted for strawberry in coastal California (Shennan et al. 2014).

We chose to include P. ultimum in our field plot bioassays because, in many California almond and peach replant soils, its incidence in roots correlates with PRD expression, and isolates of the species were pathogenic on Nemaguard peach rootstock (Schmidt and Browne 2013). All of our tested fumigation and ASD treatments provided reductions in $P$. ultimum populations in bioassay samples. It is uncertain whether the bioassay results reflected concurrent population dynamics of "natural" populations of $P$. ultimum in bulk soil of the orchard plots but results of our isolations from roots in

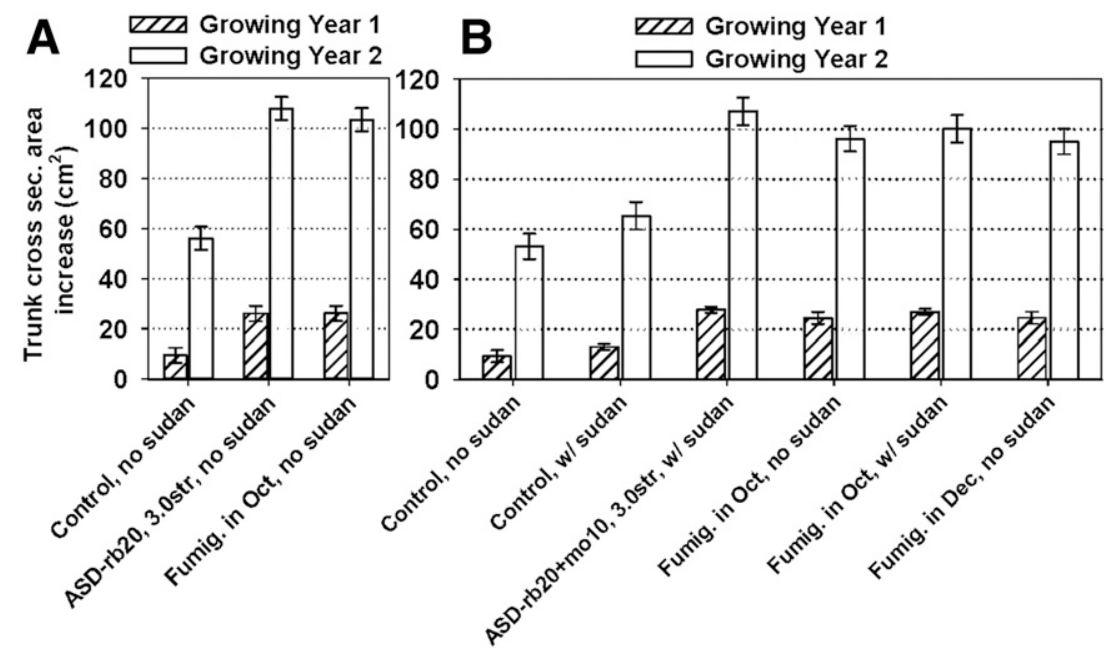

Fig. 2. Effects of preplant soil treatments on replanted almond tree growth. A and B, Tree trunk cross-section area increases after planting in experiments 1 and 2, respectively. On the $x$ axis, abbreviations of "rb20" indicate that rice bran was rototilled into soil at $20 \mathrm{t} \mathrm{ha}^{-1}$ (treated area), whereas "mo-10" indicates addition of molasses at $10 \mathrm{tha}{ }^{-1}$ via drip application. Also, "3.0-str" indicates 3.0-m-wide anaerobic soil disinfestation (ASD)-treated area, and "no-sudan" and "w/sudan" indicate treatments that were without sudangrass rotation and treatments that were preceded by sudangrass cover crop rotation, respectively. Error bars are $95 \%$ confidence intervals.

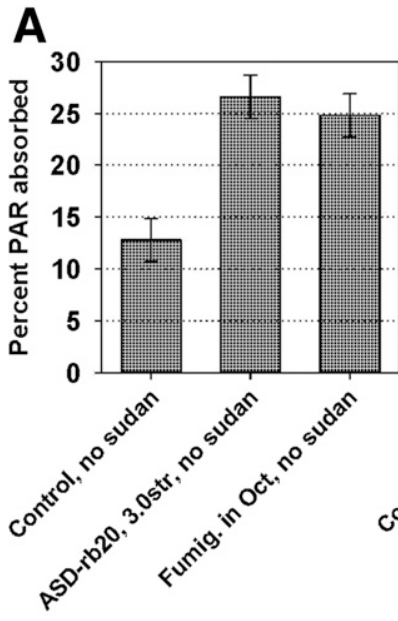

B

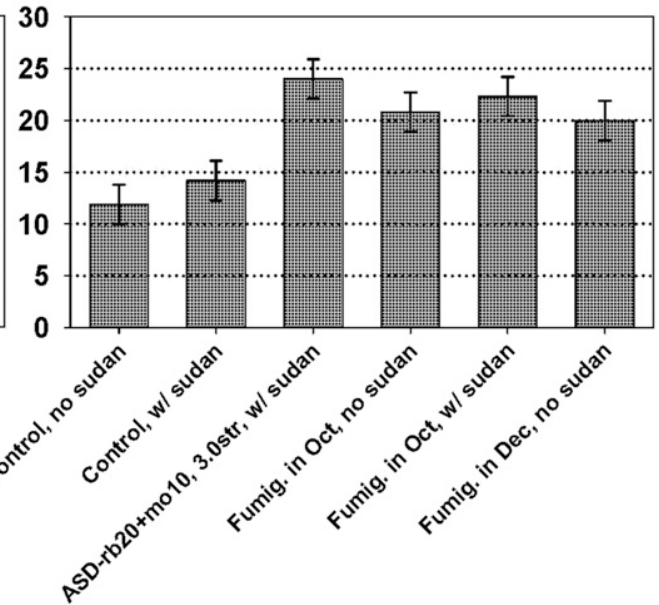

Fig. 3. Effects of preplant soil treatments on replanted almond tree growth. A and B, Midday photosynthetically active radiation (PAR) intercepted by tree canopies expressed as a percentage of total midday PAR in experiments 1 and 2, respectively, in July of growing year 2. On the x axis, abbreviations of "rb20" indicate that rice bran was rototilled into soil at $20 \mathrm{t} \mathrm{ha}^{-1}$ (treated area), whereas "mo-10" indicates addition of molasses at $10 \mathrm{tha}^{-1}$ via drip application. Also, "3.0-str" indicates 3.0-m-wide anaerobic soil disinfestation (ASD)treated area, and "no-sudan" and "w/sudan" indicate treatments that were without sudangrass rotation and treatments that were preceded by sudangrass cover crop rotation, respectively. Error bars are $95 \%$ confidence intervals. 
experiment 1 indicated that root infections by at least some species of Pythium were reduced by the preplant fumigation treatment and, to a lesser extent, by the ASD treatment. Further work is justified to examine contributions of Pythium spp. to PRD induction and effectiveness of ASD in suppressing the disease.

Our root isolations found that reduced incidence of Fusarium and Pythium spp. in Nemaguard roots of almond trees was associated with positive tree growth responses to fumigation and ASD in replant soil. Species of Pythium (and Phytopythium) have been reported previously in association with replant disease of peach and almond (Bent et al. 2009; Hine 1961; Schmidt and Browne 2013; Yang et. al. 2012). Interestingly, in this study, increased root incidence of Trichoderma spp. resulted in fumigated plots but not in ASD plots, despite equivalent growth responses to the treatments. Previously, cultureindependent examinations associated root incidence of Trichoderma asperellum and $T$. virens positively with peach seedling growth in a peach replant soil (Yang et al. 2012).

The culture-independent examinations of this study, which utilized PERManova and NMDS, also provided evidence that potentially important shifts in fungal and oomycete root communities were associated with ASD and soil fumigation treatments. Although detailed assessment of microbial community responses to ASD and soil fumigation treatments tested here were beyond the scope of this report, such examinations are underway and will be reported separately.

In future trials, it will be very important to evaluate the efficacy of ASD for control of PPN that affect orchard crops. Data from trials with apple, which shares some nematode pests with stone fruit and nuts, suggest that, in a substrate-dependent manner, ASD may be effective in suppressing phytoparasitic nematodes in perennial crops (Hewavitharana et al. 2014).

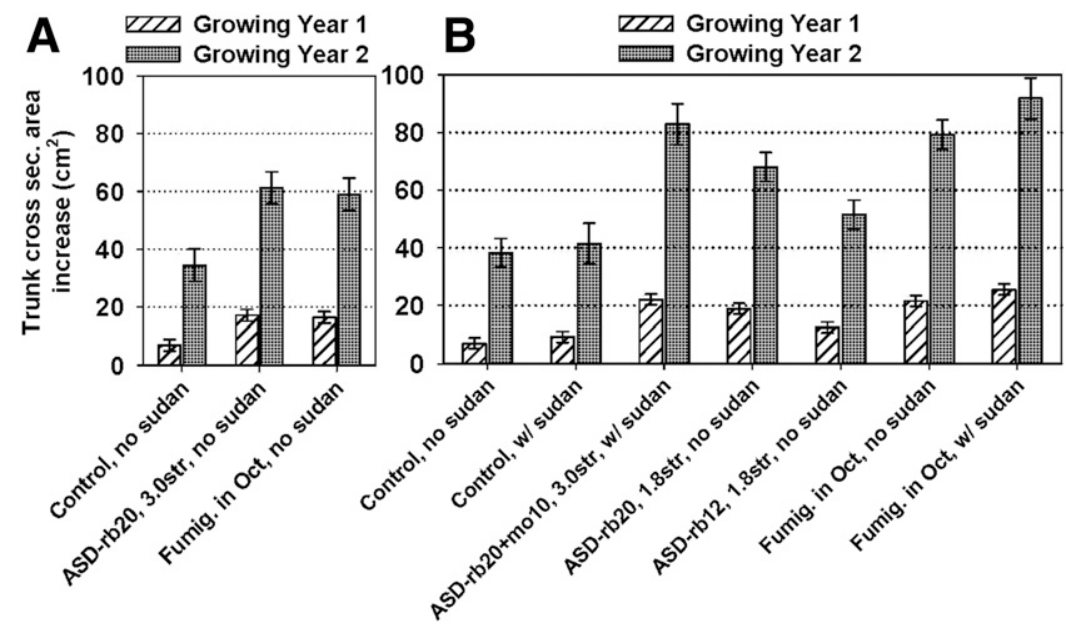

Fig. 4. Effects of preplant soil treatments on tree growth. $\mathbf{A}$ and $\mathbf{B}$, Tree trunk cross-section area increases after planting in experiments 3 and 4 , respectively. On the $x$ axis, labels of "rb20" and "rb12" indicate that rice bran was rototilled into soil at 20 and $12 \mathrm{tha}^{-1}$ (treated area), respectively, whereas "mo-10" indicates addition of molasses at $10 \mathrm{tha}{ }^{-1}$ via drip application. Also, "3.0-str" and "1.8-str" indicate 3.0- and 1.8-m-wide anaerobic soil disinfestation (ASD)-treated areas, respectively; and "no-sudan" and "w/sudan" indicate treatments that were without sudangrass rotation and treatments that were preceded by sudangrass cover crop rotation, respectively. Error bars are $95 \%$ confidence intervals.

Table 4. Isolation of culturable fungi and oomycetes from fine roots in first growing year of experiment 1

\begin{tabular}{|c|c|c|c|c|c|c|c|c|c|c|c|c|c|}
\hline \multirow[b]{2}{*}{ Treatment, medium ${ }^{b}$} & \multirow[b]{2}{*}{$\operatorname{Root}^{\mathrm{c}}$} & \multirow[b]{2}{*}{$N^{\mathbf{d}}$} & \multicolumn{11}{|c|}{ Number of root pieces yieldinga } \\
\hline & & & Alt & Asp & Cyl & Fus & Mac & Mor & Pen & Phy & Pym & $R h i$ & Tri \\
\hline \multicolumn{14}{|l|}{ Control } \\
\hline \multirow[t]{2}{*}{ PARP } & Bleach & 48 & 0 & 0 & 0 & 0 & 0 & 5 & 0 & 0 & 9 & 0 & 0 \\
\hline & Rinse & 48 & 0 & 0 & 0 & 0 & 0 & 21 & 0 & 0 & 15 & 0 & 1 \\
\hline \multirow[t]{2}{*}{ PDAa } & Bleach & 48 & 0 & 2 & 2 & 24 & 1 & 0 & 3 & 0 & 6 & 2 & 0 \\
\hline & Rinse & 48 & 5 & 1 & 0 & 26 & 0 & 9 & 1 & 0 & 11 & 3 & 6 \\
\hline Total & $\ldots$ & 192 & 5 & 3 & 2 & 50 & 1 & 35 & 4 & 0 & 41 & 5 & 7 \\
\hline \multicolumn{14}{|l|}{ ASD w/rice bran } \\
\hline \multirow[t]{2}{*}{ PARP } & Bleach & 48 & 0 & 0 & 0 & 0 & 0 & 6 & 0 & 0 & 9 & 0 & 0 \\
\hline & Rinse & 48 & 0 & 0 & 0 & 0 & 0 & 15 & 0 & 0 & 16 & 0 & 0 \\
\hline \multirow[t]{2}{*}{ PDAa } & Bleach & 48 & 0 & 0 & 0 & 1 & 0 & 3 & 6 & 0 & 0 & 0 & 4 \\
\hline & Rinse & 48 & 0 & 0 & 0 & 8 & 0 & 4 & 8 & 0 & 2 & 0 & 6 \\
\hline Total & $\ldots$ & 192 & 0 & 0 & 0 & $9 * * *$ & 0 & 28 & $14 * *$ & 0 & $27 *$ & 0 & 10 \\
\hline \multicolumn{14}{|l|}{ Fumigation in October } \\
\hline \multirow[t]{2}{*}{ PARP } & Bleach & 48 & 0 & 0 & 0 & 0 & 0 & 5 & 0 & 0 & 2 & 0 & 0 \\
\hline & Rinse & 48 & 0 & 0 & 0 & 1 & 0 & 33 & 0 & 1 & 0 & 0 & 0 \\
\hline \multirow[t]{2}{*}{ PDAa } & Bleach & 48 & 0 & 0 & 0 & 0 & 0 & 4 & 0 & 0 & 0 & 0 & 43 \\
\hline & Rinse & 48 & 0 & 0 & 0 & 0 & 0 & 3 & 0 & 0 & 2 & 0 & 46 \\
\hline Total & $\ldots$ & 192 & 0 & 0 & 0 & $1 * * *$ & 0 & $45^{* * *}$ & 0 & 1 & $4 * * *$ & 0 & $89 * * *$ \\
\hline \multicolumn{14}{|c|}{$\begin{array}{l}\text { Number of root pieces that yielded the indicated organism. Abbreviations of genera: } \text { Alt }=\text { Alternaria, Asp }=\text { Aspergillus, Cyl }=\text { Cylindrocarpon, Fus }=\text { Fusarium, } \\
\text { Mac }=\text { Macrophomina, Mor }=\text { Mortierella, Pen }=\text { Penicillium, Phy }=\text { Phytophthora, Pym }=\text { Pythium, Rhi }=\text { Rhizoctonia, and Tri }=\text { Trichoderma. Count totals } \\
\text { followed by asterisks differ from corresponding counts in the control treatment at } P=0.01(* * *), P=0.05(* *) \text {, or } P=0.10(*) \text { according to the } \chi^{2} \text { test. } \\
\text { b Soil treatment (all with no sudangrass) and culture medium. ASD }=\text { anaerobic soil disinfestation; PARP }=\text { corn meal agar amended by pimaricin, ampicillin, } \\
\text { rifampicin, and pentachloronitrobenzene; and PDAa = potato dextrose agar amended by ampicillin, as detailed in the text. } \\
\text { c Root isolation treatment. }\end{array}$} \\
\hline
\end{tabular}


Due to land and other limitations, our trials were not designed to examine possible effects of ASD treatment components. For example, our rice bran treatments added nitrogen at approximately $200 \mathrm{~kg} \mathrm{ha}^{-1}$ on an orchard basis, a substantial amount for a young orchard, although the nitrogen would not all be immediately available. It is possible that some of the ASD treatment response was due to nutritional effects but this was not investigated. Similarly, apart from possible substrate contributions to plant nutrition, we did not investigate the possibility that the high soil water content and relatively warm soil temperatures maintained for 6 weeks under ASD might, in some way, have stimulated subsequent tree growth. The fact that the Pythium bioassay inoculum was nearly eradicated by ASD treatments in our trials suggests that diverse biocidal compounds known to be generated by such treatments (Hewavitharana et al. 2014) were probably an important component of our tree growth responses to ASD. The fumigants we applied, which provided an equivalent tree growth stimulation compared with ASD treatments, directly added only relatively small amounts of plant nutrients. We are currently conducting orchard trials to examine effects and interactions among ASD treatment components.

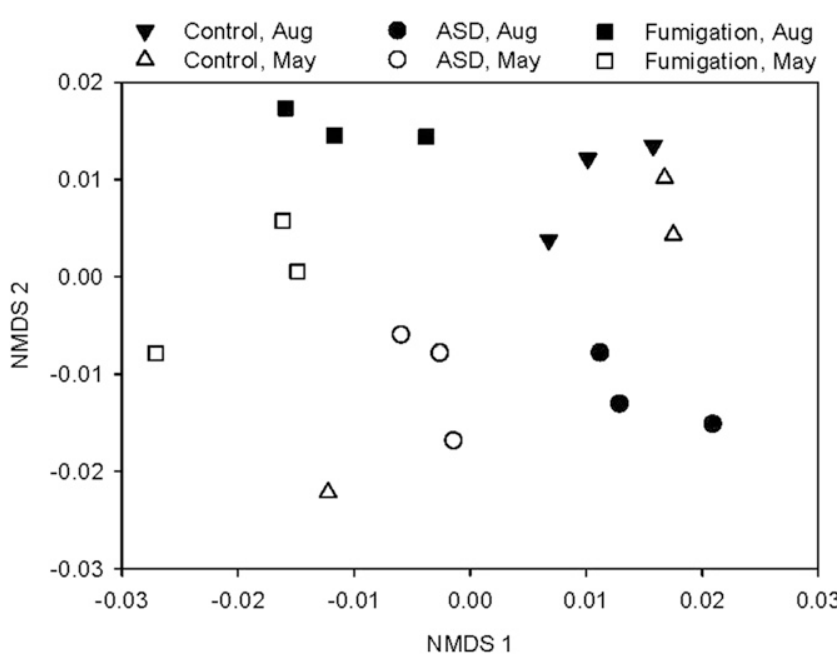

Fig. 5. Nonmetric multidimensional scaling (NMDS) ordination of Bray-Curtis distance matrices of fungal and oomycete community internal transcribed spacer amplicons from roots sampled in experiment 1 treatments (2013) in two different months (stress $=0.178)$.

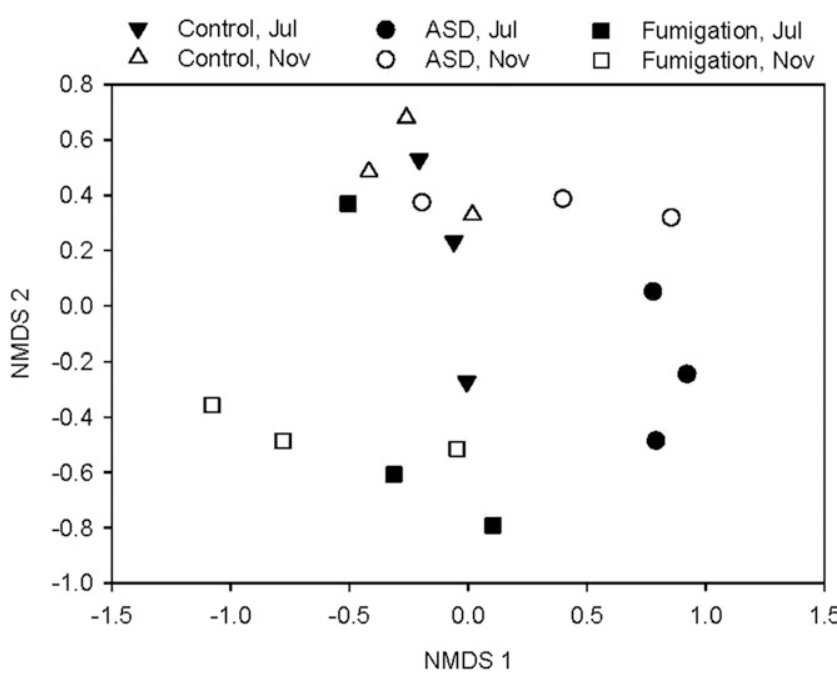

Fig. 6. Nonmetric multidimensional scaling (NMDS) ordination of Bray-Curtis distance matrices of fungal and oomycete community internal transcribed spacer amplicons from roots sampled in experiment 3 treatments (2014) in two different months (stress $=0.180$ ).

\section{Acknowledgments}

We thank the Almond Board of California and the California Department of Pesticide Regulation for partial support of this work. We are grateful to L. Froenicke, V. Rashbrook, and S. Ashtari of the DNA Technologies Core at UC Davis for contributing DNA sequencing and consulting services; M. Settles of the UC Davis Bioinformatics Core for consulting and bioinformatics support; S. Metcalf, Plant Sciences Department, UC Davis for providing PAR measurements and field assistance; G. Brar, formerly with UC Cooperative Extension, Fresno County for providing field assessments and extension outreach; A. Westphal, Department of Nematology, UC Riverside for nematode population assessments and consultations; and D. Pattigan and C. Boldwyn, both at the UC Kearney Research and Education Center, for management of farming operations.

\section{Literature Cited}

Ajwa, H., Stanghellini, M., Gao, S., Sullivan, D. A., Khan, A., Ntow, W., and Qin, R. 2013. Fumigant emission reductions with TIF warrant regulatory changes. Calif. Agric. 67:147-152.

Altschul, S. F., Gish, W., Miller, W., Myers, E. W., and Lipman, D. J. 1990. Basic local alignment search tool. J. Mol. Biol. 215:403-410.

Bálint, M., Schmidt, P.-A., Sharma, R., Thines, M., and Schmitt, I. 2014. An Illumina metabarcoding pipeline for fungi. Ecol. Evol. 4:2642-2653.

Bent, E., Loffredo, A., Yang, J. H., McKenry, M. V., Becker, J. O., and Borneman, J. 2009. Investigations into peach seedling stunting caused by a replant soil. FEMS Microbiol. Ecol. 68:192-200.

Blok, W. J., Lamers, J. G., Termorshuizen, A. J., and Bollen, G. J. 2000. Control of soilborne plant pathogens by incorporating fresh organic amendments followed by tarping. Phytopathology 90:253-259.

Bokulich, N. A., and Mills, D. A. 2013. Improved selection of internal transcribed spacer-specific primers enables quantitative, ultra-high-throughput profiling of fungal communities. Appl. Environ. Microbiol. 79:2519-2526.

Browne, G., Blackburn, N., Doll, D., Gillis, M., and Miller, D. 2015a. Soil testing and spot fumigation: Potential for reducing orchard fumigant use. Pages 74-71 to 74-72 in: Ann. Int. Res. Conf. Methyl Bromide Alt. Emiss. Red.

Browne, G. T., Connell, J. H., and Schneider, S. M. 2006. Almond replant disease and its management with alternative pre-plant soil fumigation treatments and rootstocks. Plant Dis. 90:869-876.

Browne, G. T., Lampinen, B. D., Holtz, B. A., Doll, D. A., Upadhyaya, S. K. Schmidt, L. S., Bhat, R. G., Udompetaikul, V., Coates, R. W., Hanson, B. D., Klonsky, K. M., Gao, S., Wang, D., Gillis, M., Gerik, J., and Johnson, R. S. 2013. Managing the almond and stone fruit replant disease complex with less soil fumigant. Calif. Agric. 67:128-138.

Browne, G. T., Leslie, C. A., Grant, J. A., Bhat, R. G., Schmidt, L. S., Hackett, W. P., Kluepfel, D. A., Robinson, R., and McGranahan, G. H. 2015b. Resistance to species of Phytophthora identified among clones of Juglans microcarpa $\times$ J. regia. HortScience 50:1136-1142.

Butler, D. M., Kokalis-Burelle, N., Muramoto, J., Shennan, C., McCollum, T. G., and Rosskopf, E. N. 2012. Impact of anaerobic soil disinfestation combined with soil solarization on plant-parasitic nematodes and introduced inoculum of soilborne plant pathogens in raised-bed vegetable production. Crop Prot. 39:33-40.

Catlin, P. B. 1996. Root systems and root physiology. Page 289 in: Almond Production Manual. W. C. Micke, ed. Division of Agriculture and Natural Resources, University of California, Oakland.

CDFA. 2009. Reducing smog-producing emissions from field fumigants. Sept. Update. http://www.cdpr.ca.gov/docs/dept/factshts/voc_rules_11_08.pdf.

CDFA. 2016. California Agricultural Statistics Review 2015-16. https://www. cdfa.ca.gov/statistics/PDFs/2016Report.pdf

Edgar, R. C. 2010. Search and clustering orders of magnitude faster than BLAST Bioinformatics 26:2460-2461.

Gao, S., Hanson, B. D., Qin, R., Cabrera, J., Gerik, J. S., Wang, D., and Browne, G. T. 2013. Totally impermeable film (TIF) reduces emissions in perennial crop fumigation. Calif. Agric. 67:217-221.

Hewavitharana, S. S., and Mazzola, M. 2016. Carbon source-dependent effects of anaerobic soil disinfestation on soil microbiome and suppression of Rhizoctonia solani AG-5 and Pratylenchus penetrans. Phytopathology 106: 1015-1028.

Hewavitharana, S. S., Ruddell, D., and Mazzola, M. 2014. Carbon sourcedependent antifungal and nematicidal volatiles derived during anaerobic soil disinfestation. Eur. J. Plant Pathol. 140:39-52.

Hine, R. B. 1961. The role of fungi in the peach replant problem. Plant Dis. Rep. 45:462-466.

Husson, O. 2013. Redox potential $\left(E_{h}\right)$ and $\mathrm{pH}$ as drivers of soil/plant/microorganism systems: A transdisciplinary overview pointing to integrative opportunities for agronomy. Plant Soil 362:389-417.

Lampinen, B., Udompetaikul, V., Browne, G., Metcalf, S., Stewart, W., Contador, L., Negron, C., and Upadhaya, S. 2012. A mobile platform for measuring canopy photosynthetically active radiation interception in orchard systems. HortTechnology 22:237-244.

Masella, A. P., Bartram, A. K., Truszkowski, J. M., Brown, D. G., and Neufeld J. D. 2012. PANDAseq: Paired-end assembler for Illumina sequences. BMC Bioinf. 13:31.

McKenry, M. V. 1999. The Replant Problem and Its Management. Catalina Publishing, Fresno, CA 
McKenry, M. V., and Kretsch, J. 1987. Survey of nematodes associated with almond production in California. Plant Dis. 71:71-73.

McMurdie, P. J., and Holmes, S. 2013. phyloseq: An R package for reproducible interactive analysis and graphics of microbiome census data. PLoS One 8:e61217.

Messiha, N. S., van Diepeningen, A., Wenneker, M., van Beuningen, A., Janse, J., Coenen, T. C., Termorshuizen, A., van Bruggen, A. C., and Blok, W. 2007. Biological soil disinfestation (BSD), a new control method for potato brown rot, caused by Ralstonia solanacearum race 3 biovar 2. Eur. J. Plant Pathol. 117:403-415.

Momma, N., Kobara, Y., Uematsu, S., Kita, N., and Shinmura, A. 2013. Development of biological soil disinfestations in Japan. Appl. Microbiol. Biotechnol. 97:3801-3809.

Momma, N., Usami, T., Amemiya, A., and Shishido, M. 2005. Factors involved in the suppression of Fusarium oxysporum f. sp. lycopersici by soil reduction. Soil Microorg. 59:27-33.

Oksanen, J., Blanchette, F., Friendly, M., Kindt, R., Legendre, P., McGlinn, D., Minchin, P., O’Hara, R., Simpson, G., Solymos, P., Stevens, M., Szoecs, E., and Wagner, H. 2016. Vegan: Community ecology package. Online publication. https://cran.r-project. org, https://github.com/vegandevs/vegan

R Core Development Team. 2016. R: A language and environment for statistical computing. R Foundation for Statistical Computing, Vienna, Austria. https:// www.R-project.org/

Schloss, P. D., Westcott, S. L., Ryabin, T., Hall, J. R., Hartmann, M., Hollister, E. B., Lesniewski, R. A., Oakley, B. B., Parks, D. H., Robinson, C. J., Sahl, J. W., Stres, B., Thallinger, G. G., Van Horn, D. J., and Weber, C. F. 2009. Introducing mothur: Open-source, platform-independent, community-supported software for describing and comparing microbial communities. Appl. Environ. Microbiol. 75: 7537-7541.

Schmidt, L. S., and Browne, G. T. 2013. Characterization of Pythium species associated with Prunus replant disease. (Abstr.) Phytopathology 103:S2.128.

Shennan, C., Muramoto, J., Mazzola, M., Momma, N., Kobara, Y., Lamers, J., Rosskopf, E., Kokalis-Burelle, N., and Butler, D. 2014. Anaerobic soil disinfestation for soil borne disease control in strawberry and vegetable systems: Current knowledge and future directions. Acta Hortic. 1044:165-175.

Shinmura, A. 2004. Principle and effect of soil sterilization methods by reducing the redox potential of soil. PSJ Soilborne Dis. Workshop Rep. 22:2-12.

Strauss, S. L., Greenhut, R. F., McClean, A. E., and Kluepfel, D. A. 2017. Effect of anaerobic soil disinfestation on the bacterial community and key soilborne phytopathogenic agents under walnut tree-crop nursery conditions. Plant Soil 415:493-506.

Strauss, S. L., and Kluepfel, D. A. 2015. Anaerobic soil disinfestation: A chemicalindependent approach to pre-plant control of plant pathogens. J. Integr. Agric. 14:2309-2318

Wang, Q., Garrity, G. M., Tiedje, J. M., and Cole, J. R. 2007. Naïve Bayesian classifier for rapid assignment of rRNA sequences into the new bacterial taxonomy. Appl. Environ. Microbiol. 73:5261-5267.

Yang, J.-i., Ruegger, P. M., McKenry, M. V., Becker, J. O., and Borneman, J. 2012. Correlations between root-associated microorganisms and peach replant disease symptoms in a California soil. PLoS One 7:e46420. 